\title{
XENOLITHS FROM THE ARNIE, MISERY AND PIGEON KIMBERLITES, EKATI MINE, NWT, CANADA.
}

\author{
Patricia M. Doyle ${ }^{1}$, John J. Gurney ${ }^{1,2}$ and Anton le Roex ${ }^{1}$ \\ ${ }^{1}$ University of Cape Town, South Africa; ${ }^{2}$ Mineral Services (Pty) Ltd, South Africa
}

\section{INTRODUCTION}

Eighty-five peridotitic and pyroxenitic xenoliths from the Arnie, Pigeon and Misery kimberlites in the Lac de Gras region, Northwest Territories, Canada have been studied. Rock types were determined using mineral associations The three kimberlites are situated within a $40 \mathrm{~km}$ radius of within the xenolith in conjunction with mineral compositions one another on the Ekati property (figure 1), and all are ( $\mathrm{CaO}$ and $\mathrm{Cr}_{2} \mathrm{O}_{3}$ in garnet; Gurney, 1984). Xenoliths diamond-bearing.

The high proportion of garnet-harzburgites entrained in these kimberlites made for an interesting major and trace element study (Doyle, 2002). Xenolith geotherms were computed using both major- and trace element geothermobarometry.

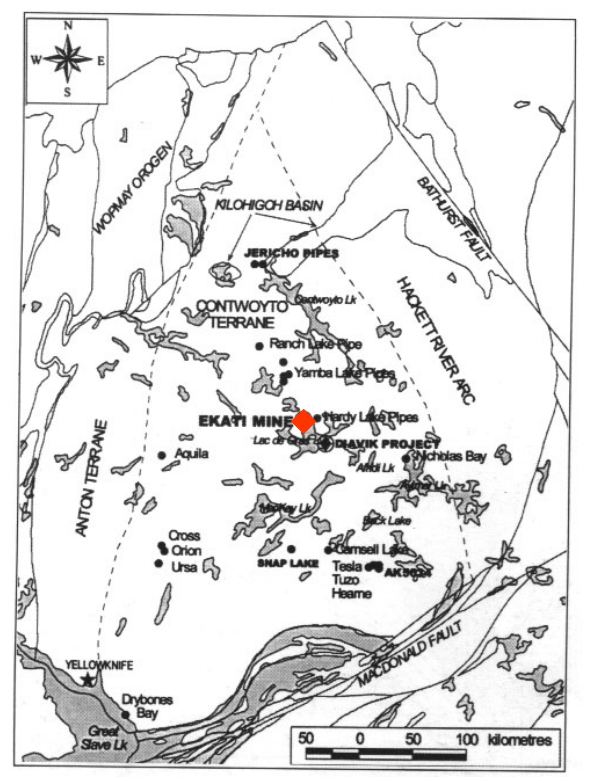

Figure 1 The three kimberlites are situated within a $40 \mathrm{~km}$ radius of one another on the Ekati property, NWT, Canada. (Base map: Carlson et al., 1999)

\section{ANALYTICAL TECHNIQUES}

Major and trace element analysis followed a petrographic study of the xenoliths. Major element compositions of individual minerals were determined using a wavelength dispersive electron microprobe, and trace element abundances were determined using laser ablation ICP-MS. Pressures and temperatures of equilibration were then determined using garnet-olivine, garnet-orthopyroxene and trace element geothermobarometers $\left(\mathrm{T}_{\mathrm{Ni}}, \mathrm{P}_{\mathrm{Cr}}\right)$.

\section{RESULTS AND CONCLUSIONS}

\section{PETROGRAPHY}

containing garnet were preferentially selected for geothermobarometric and mineral compositional studies. The peridotite suite consisted of both garnet-harzburgites and garnet-lherzolites, whereas the pyroxenitic suite consisted of garnet-clinopyroxenites and garnet-websterites. Harzburgites were regarded as those xenoliths that contained no clinopyroxene (Dawson, 1981).

Peridotite xenoliths were dominant at all three kimberlite localities. Spinel exsolution from ortho- and clinopyroxene in both peridotitic and pyroxenitic xenoliths from the Misery and Arnie kimberlites is indicative of partial re-equilibration temperature to lower pressure and temperature (Harte and Gurney, 1975). Such dynamic processes and small scale heterogeneity suggest a complex history for the lithosphere beneath the Slave province.

\section{Major and Trace Element Mineral Chemistry}

Pyroxenitic minerals are more Fe-rich and $\mathrm{Cr}_{2} \mathrm{O}_{3}$-poor than the peridotitic minerals (Doyle, 2002). The harzburgitic xenoliths were divided into two sub-groups based on $\mathrm{CaO}$ and $\mathrm{Cr}_{2} \mathrm{O}_{3}$ content in garnet (Gurney, 1984), namely a high$\mathrm{Ca}$ group and a low-Ca group. Major and trace element compositions of selected peridotitic and pyroxenitic xenoliths are detailed in tables 1 and 2, and depicted in figures 2, 3 and 4 . The major element composition of the high-Ca harzburgitic garnets are similar to the lherzolitic garnets (figure 3), whereas the trace element characteristics of the high-Ca harzburgitic garnets are more alike the lowCa harzburgites (figure 4).

The lherzolitic and pyroxenitic garnets have chondritenormalised LREE-depleted patterns (figure 5), whereas the harzburgitic garnets have sinusoidal and MREE-enriched patterns in addition to the LREE-depleted pattern. Many authors have speculated about the origin of the MREEenriched garnet pattern (Hoal et al., 1994; Shimizu and Sobelev, 1995; Griffin et al., 1999(a)), but not the sinusoidal pattern. Doyle (2002) tentatively speculates that the sinusoidal pattern of the pyrope may be retained from the of these xenoliths from a region of high pressure and 
exsolution of pyrope and orthopyroxene from a pre-existing garnets (both low-Ca and high-Ca) were more enriched in majorite component. The LREE-depleted chondrite $\mathrm{Nb}$ than the lherzolitic and pyroxenitic garnets (table 2, normalized garnet pattern would however be produced if figures 4 and 5), whereas the lherzolitic garnets were more pyrope and clinopyroxene were the exsolution products. enriched in $\mathrm{Y}$ and $\mathrm{Ti}$ than the harzburgitic and pyroxenitic garnets. The lherzolitic garnets have higher $\mathrm{Zr}$ abundances

The trace elements $\mathrm{Nb}, \mathrm{Y}, \mathrm{Zr}$ and $\mathrm{Ti}$ discriminated well than the pyroxenitic garnets (figure 6).

between the different xenoliths: In general the harzburgitic

Table 1: Major element compositions of garnet of selected xenoliths.

\begin{tabular}{|c|c|c|c|c|c|c|c|c|c|c|}
\hline Suite: & Low-Ca & Low-Ca & Low-Ca & Low-Ca & High-CA & High-Ca & Lhz & Lhz & Clino & Web \\
\hline SampleNo. & ARN007 & ARN008 & ARN025 & ARN026 & ARN003 & ARN006 & MIS409 & PGN337 & ARN028 & MIS438 \\
\hline $\mathrm{SiO}_{2}$ & 41.36 & 42.18 & 41.59 & 42.28 & 40.93 & 41.20 & 41.68 & 42.28 & 40.59 & 38.91 \\
\hline $\mathrm{TiO}_{2}$ & $<0.04 *$ & $<0.04$ & $<0.04$ & 0.04 & $<0.04$ & $<0.04$ & $<0.04$ & 0.62 & 0.11 & 0.08 \\
\hline $\mathrm{Al}_{2} \mathrm{O}_{3}$ & 18.20 & 20.11 & 18.97 & 20.96 & 17.94 & 19.70 & 21.24 & 20.77 & 19.67 & 22.26 \\
\hline $\mathrm{Cr}_{2} \mathrm{O}_{3}$ & .12 & 4.91 & 7.26 & 4.70 & 8.02 & 5.50 & 3.64 & 3.39 & 4.17 & 0.44 \\
\hline $\mathrm{FeO}$ & 6.99 & 7.78 & 7.07 & 7.36 & 7.06 & 8.22 & 8.16 & 8.50 & 12.66 & 22.03 \\
\hline MnO & 0.42 & 0.43 & 0.42 & 0.40 & 0.48 & 0.58 & 0.41 & 0.35 & 0.48 & 0.51 \\
\hline MgO & 22.63 & 22.47 & 20.95 & 20.49 & 19.19 & 18.92 & 19.36 & 19.47 & 16.38 & 10.25 \\
\hline $\mathrm{CaO}$ & 2.96 & 1.35 & 3.49 & 3.96 & 6.60 & 5.92 & 5.17 & 4.92 & 6.09 & 5.66 \\
\hline $\mathrm{Na}_{2} \mathrm{O}$ & 0.04 & 0.03 & 0.04 & 0.02 & 0.04 & 0.04 & 0.02 & ND & 0.02 & 0.02 \\
\hline Total & 99.73 & 99.27 & 99.79 & 100.21 & 100.27 & 100.09 & 99.68 & 100.48 & 100.18 & 100.14 \\
\hline Mg\# & 85.23 & 83.74 & 84.09 & 83.22 & 82.90 & 80.41 & 80.89 & 80.33 & 69.76 & 45.35 \\
\hline \# Anal & 7 & 9 & 11 & 5 & 4 & 5 & 5 & 4 & 8 & 3 \\
\hline
\end{tabular}

Key: $<0.04=<$ Lower Limit of Detection. Low-Ca = Low-Ca harzburgite, High-Ca = High-Ca harzburgite,

$\mathrm{Lhz}=$ Lherzolite, Clino $=$ Clinopyroxenite, $\mathrm{Web}=$ Websterite

Table 2: Trace element abundances in garnet of selected xenoliths, NWT

\begin{tabular}{|l|r|r|r|r|r|r|r|r|}
\hline Suite & Low-Ca & Low-Ca & Low-Ca & High-Ca & High-Ca & Lhz & Lhz & Pyrox \\
\hline Sample No & ARN007 & ARN025 & PGN314 & ARN003 & ARN004 & MIS409 & PGN337 & ARN028 \\
\hline Ti & 56 & $<25.62$ & 371 & 125 & 38 & 567 & 2850 & 537 \\
\hline Sr & 1.2 & 1.8 & 0.57 & 1.8 & 1.8 & 0.22 & 0.54 & $<0.37$ \\
\hline Y & 0.65 & $<0.71$ & 2.1 & 35 & 1.2 & 8.6 & 12 & 9.6 \\
\hline Zr & 32 & 53 & 29 & 107 & 3.3 & 4.7 & 27 & 1.9 \\
\hline Nb & 0.33 & 0.50 & $<0.22$ & 1.3 & 0.090 & 0.34 & 0.44 & 0.77 \\
\hline La & 0.13 & 0.92 & 0.44 & 0.25 & 0.67 & 0.05 & $<0.43$ & $<0.43$ \\
\hline Ce & 1.3 & 2.3 & 0.44 & 2.0 & 5.4 & 0.15 & 0.16 & 0.27 \\
\hline Nd & 5.2 & 9.4 & 1.4 & 7.7 & 6.2 & 0.27 & 0.75 & 0.54 \\
\hline Sm & 3.4 & 5.1 & 0.50 & 5.5 & 0.92 & 0.36 & 0.54 & $<0.26$ \\
\hline Eu & 0.94 & 1.3 & 0.58 & 2.4 & 0.25 & 0.24 & $<0.54$ & $<0.54$ \\
\hline Gd & 2.2 & 3.6 & 0.85 & 10.2 & 0.49 & 1.2 & 1.3 & $<0.41$ \\
\hline Dy & 0.39 & 0.68 & 0.79 & 8.8 & 0.16 & 1.8 & 2.1 & 1.7 \\
\hline Er & $<0.054$ & 0.66 & 0.57 & 3.2 & 0.15 & 1.2 & 1.4 & 1.3 \\
\hline Yb & 0.16 & 0.30 & 0.56 & 2.2 & 0.26 & 1.3 & 1.6 & 1.3 \\
\hline Garnet REE \\
pattern
\end{tabular}

Key: $<25.26=<$ Lower Limit of Detection. Suite definitions as for Table 1 (see above). 

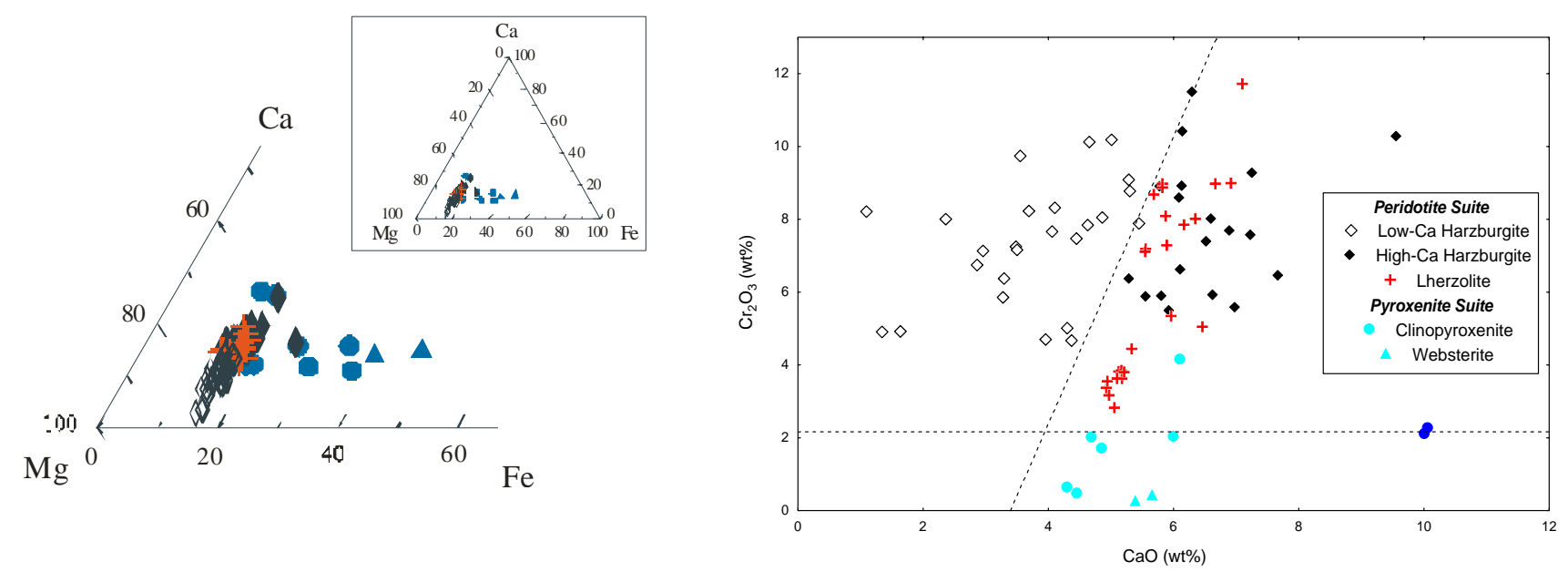

Figure $2 \mathrm{Fe}-\mathrm{Mg}-\mathrm{Ca}$ of garnet from mantle xenoliths from three kimberlite localities, NWT (symbols as for figure 3 ).

Figure $3 \mathrm{CaO}$ vs $\mathrm{Cr}_{2}-\mathrm{O}_{3}$ in garnet from mantle xenoliths from the Arnie, Pigeon and Misery kimberlites, NWT.
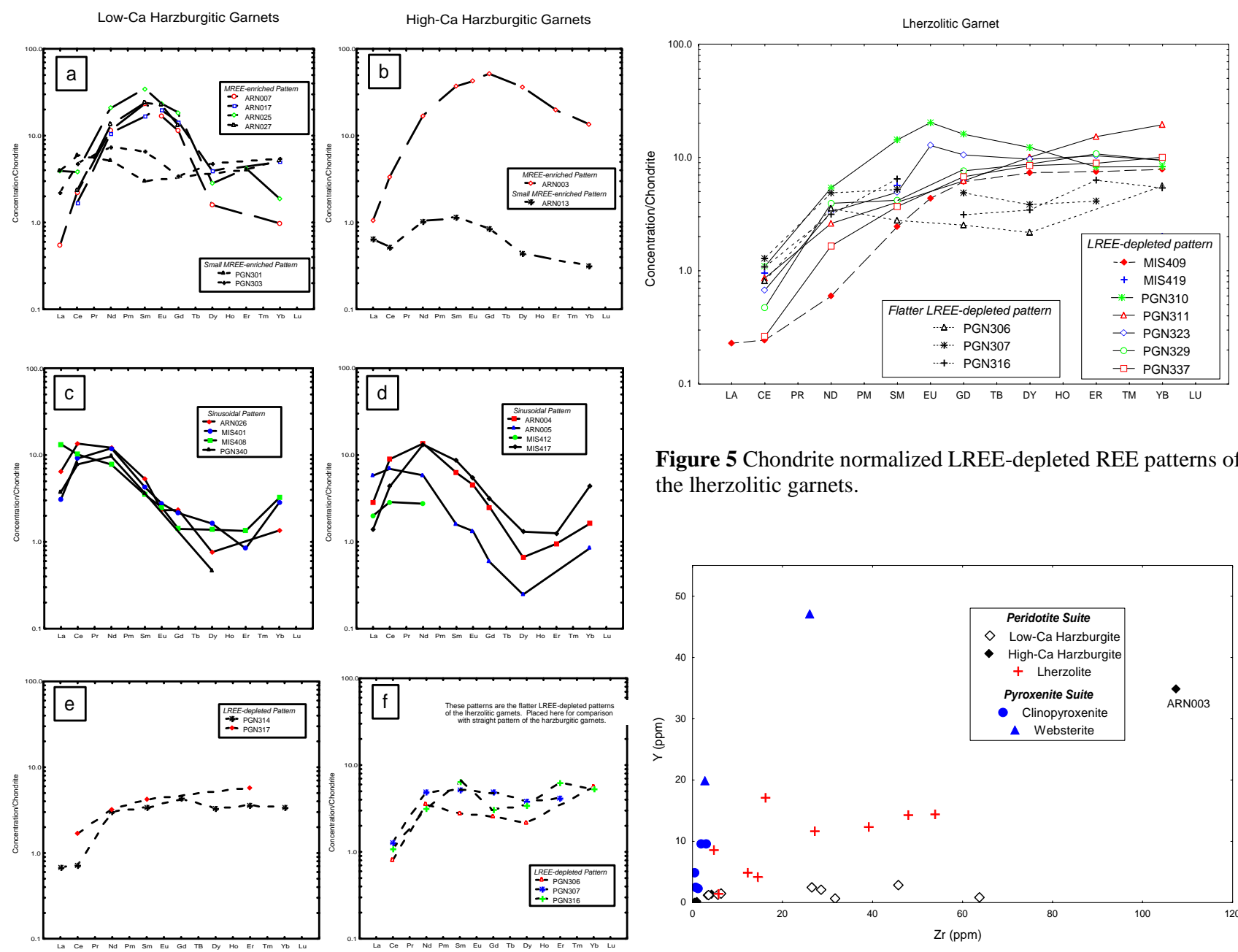

Figure 5 Chondrite normalized LREE-depleted REE patterns of the lherzolitic garnets.

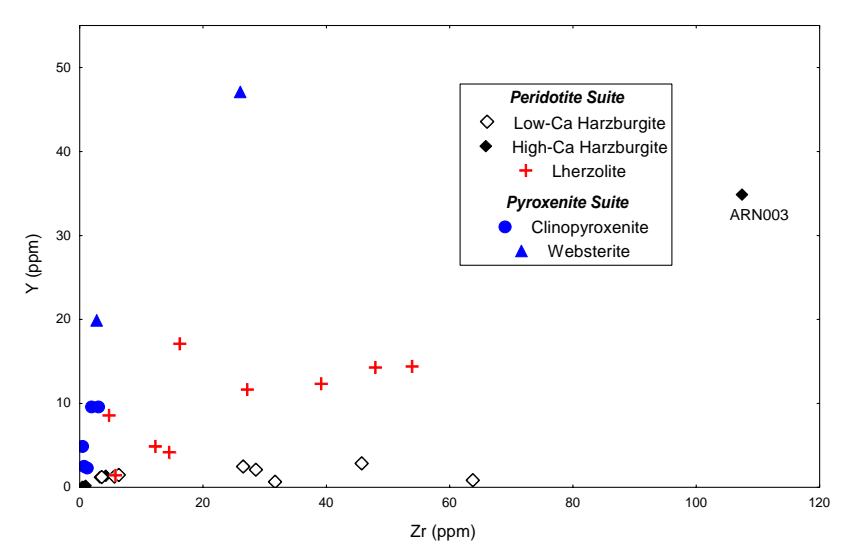

Figure 4 Chondrite normalized REE-patterns of the low-ca and high-Ca harzburgitic garnets. The low-Ca and high-Ca harzburgitic garnets have similar REE characteristics.

Figure $6 \mathrm{Y}$ vs $\mathrm{Zr}$ in garnet. The lherzolitic garnets are more enriched in $\mathrm{Y}$ than the harzburgitic garnets, and more enriched in $\mathrm{Zr}$ than the pyroxenitic garnets. 


\section{Major and Trace Element Geothermobarometry}

Major and trace element geothermobarometry reveal that the equilibration within the diamond stability field. Xenoliths peridotitic xenoliths define a $40 \mathrm{~mW} \cdot \mathrm{m}^{-2}$ geotherm (Pollack with 6-8 wt $\% \mathrm{Cr}_{2} \mathrm{O}_{3}$ straddle the graphite-diamond stability and Chapman, 1977). Major element geothermobarometry field (Kennedy and Kennedy, 1976).

indicates that although there are geochemical similarities

between the low-Ca garnets in harzburgites and peridotitic Pioneering studies of the Slave craton have recognised garnets included in diamond, not all low-Ca harzburgites layering within the underlying lithospheric mantle (Griffin et have pressures and temperatures of equilibration in the al., 1999 (b); Pearson et al., 1999; Kopylova and Russell, diamond stability field (table 3, figure 7). Low-Ca 2000). This study suggests that the harzburgites and harzburgitic xenoliths with $<6 \mathrm{wt} \% \mathrm{Cr}_{2} \mathrm{O}_{3}$ in garnet (e.g. lherzolites are inter-mixed rather than separated into two ARN008, ARN026) have shallow pressures and distinct layers (figure 8).

temperatures of equilibration. In contrast, the low-Ca and

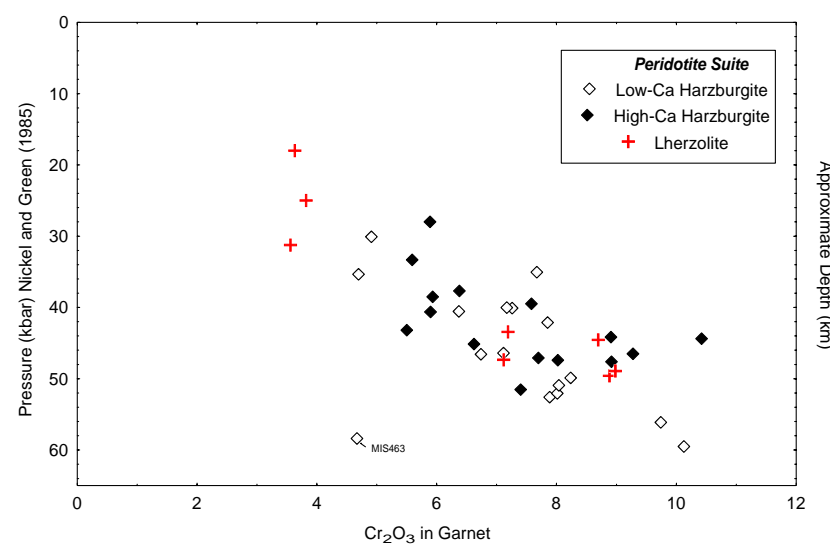

Figure 7 Pressure (Nickel and Green, 1985) vs $\mathrm{Cr}_{2} \mathrm{O}_{3}$ in garnet. There is a direct relationship between $\mathrm{Cr}_{2} \mathrm{O}_{3}$ content in garnet and pressure, as described in the text.

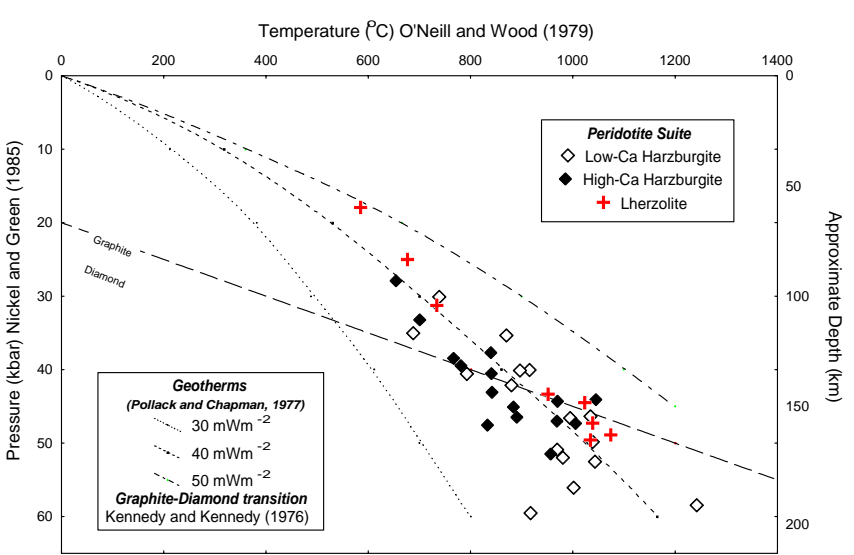

Figure 8 Pressure vs temperature. The lherzolites and harzburgites from the Pigeon, Arnie and Misery kimberlite localities appear to be interlayered, lying along

Table 3: Temperature, Pressure and $\mathrm{Cr}_{2} \mathrm{O}_{3}$ content in garnet of selected xenoliths, NWT

\begin{tabular}{|l|c|c|c|c|l|}
\hline $\begin{array}{c}\text { Kimberlite } \\
\text { Locality }\end{array}$ & Sample No. & $\begin{array}{c}\text { O'Neill \& Wood } \\
\left.\text { gt-ol } \mathbf{(}^{\mathbf{o}} \mathbf{C}\right)\end{array}$ & $\begin{array}{c}\text { Nickel \& Green } \\
\text { gt-opx (Kbar) }\end{array}$ & $\begin{array}{c}\mathbf{C r}_{\mathbf{2}} \mathbf{O}_{\mathbf{3}} \text { content } \\
\text { in Garnet }\end{array}$ & \multicolumn{1}{|c|}{ Rock Suite } \\
\hline Misery & MIS426 & 735 & 31.2 & 3.56 & Lherzolite \\
\hline Arnie & ARN026 & 871 & 35.3 & 4.70 & Low-Ca Harzburgite \\
\hline Arnie & ARN008 & 738 & 30.1 & 4.91 & Low-Ca Harzburgite \\
\hline Misery & MIS430 & 768 & 38.5 & 5.93 & High-Ca Harzburgite \\
\hline Arnie & ARN007 & 1035 & 46.4 & 7.12 & Low-Ca Harzburgite \\
\hline Pigeon & PGN339 & 1039 & 47.3 & 7.12 & Lherzolite \\
\hline Arnie & ARN003 & 1006 & 47.4 & 8.02 & High-Ca Harzburgite \\
\hline Arnie & ARN002 & 969 & 50.9 & 8.04 & Low-Ca Harzburgite \\
\hline Pigeon & PGN314 & 1039 & 49.9 & 8.24 & Low-Ca Harzburgite \\
\hline Pigeon & PGN316 & 1024 & 44.5 & 8.69 & Lherzolite \\
\hline Pigeon & PGN312 & 1045 & 44.1 & 8.91 & High-Ca Harzburgite \\
\hline Misery & MIS408 & 917 & 59.5 & 10.13 & Low-Ca Harzburgite \\
\hline
\end{tabular}




\section{REFERENCES}

Carlson J.A., Kirkley M.B., Thomas E.M. and Hillier W.D. 1999 Recent Canadian Kimberlite Discoveries. In: Proceedings of the seventh international kimberlite conference, Cape Town. Eds.: Gurney J.J., Gurney J.L., Pascoe M.D. and Richardson S.H. p 81-89

Dawson J.B. 1981 The nature of the upper mantle. Hallimond Lecture to the mineralogical society of Great Britain and Ireland, 1980. Mineralogical Magazine, 44, p 1-18

Doyle P.M. 2002 A petrographic and geochemical study of selected peridotitic and pyroxenitic xenoliths from three kimberlite localities in the Lac de Gras region, Northwest Territories, Canada. MSc Thesis, University of Cape Town, South Africa

Griffin W.L., Doyle B.J., Ryan C.G., Pearson N.J., O'Reilly S.Y., Natapov L., Kivi K., Kretschmar U. and Ward J. 1999(b) Lithospheric Structure and mantle terranes: Slave craton, Canada. In: Proceedings of the seventh international kimberlite conference, Cape Town. Eds. Gurney J.J., Gurney J.L., Pascoe M.D. and Richardson S.H. p 644-658

Griffin W.L., Shee S.R., Ryan C.G., Win T.T. and Wyatt B.A. 1999(a) Harzburgite to lherzolite and back again: metasomatic processes in ultramafic xenoliths from the Wesselton kimberlite, Kimberley, South Africa. Contributions to Mineralogy and Petrology, 134, p 232-250

Gurney J.J. 1984 A correlation between garnets and diamonds in kimberlites. In: Kimberlites occurrence and origin; a basis for conceptual models in exploration. Eds: Glover J.E. and Harris P.G. Univ. West Australia, Geology Dept. and Extension Service. Perth, West Australia, p 143-166

Harte B. and Gurney J.J. 1975 Evolution of clinopyroxene and garnet in an eclogite nodule from the Roberts Victor kimberlite pipe, South Africa. Phys. Chem. Earth, 9. p 367-387

Hoal K.E.O., Hoal B.G., Erlank A.J. and Shimizu N. 1994 Metasomatism of the mantle lithosphere recorded by rare earth elements in garnets. Earth and Planetary Science Letters, 126, p 303-313

Kennedy C.S. and Kennedy G.C. 1976 The equilibrium boundary between graphite and diamond. $J$ Geophysical Research, 73, p 2467-2470

Kopylova M.G. and Russell J.K. 2000 Chemical stratification of cratonic lithosphere: constraints from the Northern Slave craton, Canada. Earth and Planetary Science Letters, 181, p 71-87

Nickel and Green 1985 Empirical geothermobarometry for garnet peridotites and implications for the nature of the lithosphere, kimberlites and diamonds. Earth and Planetary Science Letters, 73, p 158-170

O'Neill H. St.C. 1980 An experimental Study of the Fe-Mg partitioning between garnet and olivine and its calibration as a geothermometer: corrections.

Contributions to Mineralogy and Petrology. 72 p 337

O'Neill H. St.C. and Wood B.J. (1979) An experimental study of the Fe-Mg partitioning between garnet and olivine and its calibration as a geothermometer. Contributions to Mineralogy and Petrology. 70 p 5970 With corrections (O'Neill, 1980)

Pearson N.J., Griffin W.L., Doyle B.J., O'Reilly S.Y., Van Achterbergh E. and Kivi K. 1999 Xenoliths from the kimberlite pipes from the Lac de Gras Area, Slave Craton, Canada. In: Proceedings of the seventh international kimberlite conference, Cape Town. Eds.: Gurney J.J., Gurney J.L., Pascoe M.D. and Richardson S.H. p 644-658

Pollack H.K. and Chapman D.S. 1977 The flow of heat from the earth's interior. Scientific American, 237 (2), p 60-68, 73-76

Shimizu N. and Sobolev N.V. 1995 Young peridotitic diamonds from the Mir kimberlite pipe. Nature, 375, p 394-397

Contact: Trish Doyle, P.O. Box 31316, Tokai, 7966.

E-mail: geo-odyssey@ananzi.co.za 